\title{
PENGARUH SIZE, ROA, DAN DER TERHADAP PENGUNGKAPAN \\ TANGGUNG JAWAB SOSIAL PERUSAHAAN (STUDI PADA PERUSAHAAN PROPERTY AND REAL ESTATE YANG TERDAFTAR DI \\ BURSA EFEK INDONESIA TAHUN 2015 - 2017)
}

\author{
Tagor Darius Sidauruk, SE., M.Si \\ Jahormin Simarmata, SE., M.Ak., Ak \\ Desy Wulandari \\ tagor.darius@yahoo.com, jahormin.simarmata@gmail.com \\ Fakultas Ekonomi-Program Studi Akuntansi \\ Universitas Satya Negara Indonesia
}

\begin{abstract}
ABSTRAK
Corporate Social Responsibility (CSR) adalah suatu tindakan yang dilakukan oleh perusahaan sebagai bentuk tanggung jawab sosial mereka terhadap lingkungan sekitar dimana perusahaan itu berada. Tujuan dari penelitian ini adalah untuk mengetahui bagaimana pengaruh Size, Return On Assets (ROA), dan Debt To Equity Ratio (DER) terhadap pengungkapan tanggung jawab sosial perusahaan pada subsektor Property and Real Estate yang terdaftar di BEI tahun 2015-2017.

Data yang digunakan adalah data sekunder berupa laporan tahunan 2015-2017 dari populasi perusahaan Property and Real Estate sebanyak 48 perusahaan, dan yang memenuhi kriteria sampel pada penelitian ini berjumlah 20 sampel. Metode pengumpulan data dalam penelitian ini menggunakan dokumentasi, data yang dibutuhkan tersebut diambil melalui website Bursa Efek Indonesia. Metode analisis data dalam penelitian ini yaitu Analisis Statistik Deskriptif, Uji Asumsi Klasik, Analisis Linier Berganda, dan Pengujian Hipotesis.

Hasil penelitian ini menunjukkan bahwa secara simultan ketiga variabel independen (Size, ROA, dan DER) berpengaruh positif terhadap pengungkapan tanggung jawab sosial perusahaan. Secara parsial untuk variabel Size dan ROA tidak berpengaruh secara signifikan terhadap pengungkapan tanggung jawab sosial perusahaan, sedangkan untuk variabel DER berpengaruh positif terhadap pengungkapan tanggung jawab sosial perusahaan.
\end{abstract}

Kata Kunci : Size, ROA, DER, Pengungkapan Tanggung Jawab Sosial Perusahaan 


\section{PENDAHULUAN}

\section{Latar Belakang}

Dalam beberapa tahun terakhir permasalahan lingkungan hidup merupakan isu utama yang terus diperbincangkan masyarakat dunia. Banyaknya kerugian yang terjadi akibat pengelolaan lingkungan yang tidak bertanggung jawab, baik yang dilakukan secara individu atau pun bersifat kelompok dengan mengatasnamakan organisasi. Untuk mengurangi dampak kerusakan lingkungan masing masing perusahaan wajib melakukan Corporate social responsibility. Salah satu kunci untuk meningkatkan Corporate social responsibility juga tidak terlepas dari kemampuan manajemen untuk mengelola kinerja keuangan yang fundamental, seperti leverage profitabilitas dan size. Masing masing rasio pengukuran kinerja memiliki kontribusi yang berbeda bagi eksistensi perusahaan (Saputra, 2016).

CSR (Corporate Social Responsibility) adalah suatu tindakan yang dilakukan oleh perusahaan sebagai bentuk tanggung jawab mereka terhadap sosial/lingkungan sekitar dimana perusahaan itu berada. Secara teoritis CSR merupakan inti dari etika bisnis, dimana suatu perusahaan tidak hanya mempunyai kewajiban - kewajiban ekonomis dan legal kepada pemegang saham (shareholders), tetapi juga mempunyai kewajiban terhadap pihak lain yang berkepentingan (stakeholders).

Laporan keuangan tahunan merupakan salah satu media potensial bagi perusahaan untuk menginformasikan kepada stakeholder mengenai informasi yang dihasilkan dari transaksi yang dilakukan perusahaan. Pengungkapan tanggung jawab sosial dalam laporan keuangan tahunan perusahaan akan memberikan nilai tersendiri bagi perusahaan yang go public.

Ukuran perusahaan merupakan salah satu karakteristik perusahaan yang sangat penting. Ukuran perusahaan merupakan suatu pengukuran yang dikelompokkan berdasarkan besar kecilnya perusahaan dan dapat menggambar kan aktivitas serta pendapatan perusahaan. Semakin besar ukuran perusahaan maka semakin besar usaha yang dilakukan perusahaan untuk menarik perhatian masyarakat. (Oyelere, Wang dan Song, 2011) dalam Nugraha, (2015) menjelaskan bahwa semakin besar ukuran perusahaan maka akan semakin disorot oleh stakeholder. Dengan demikian, perusahaan harus bekerja lebih keras untuk memperoleh legitimasi dari stakeholder sebagai langkah penyelarasan aktivitas perusahaan dengan nilai dan norma yang berlaku di masyarakat.

Profitabilitas merupakan faktor yang membuat manajemen menjadi bebas dan fleksibel untuk mengungkapkan pertanggung jawaban sosial kepada pemegang saham sehingga semakin tinggi tingkat profitabilitas perusahaan maka akan semakin besar pula pengungkapan pertanggung jawaban sosialnya (Grey, et all 1995 dalam Tasya, 2016).

Profitabilitas dapat diukur dengan menggunakan Return On Assets (ROA). Hery (2016, hal.193) menyatakan bahwa Return On Assets (ROA) merupakan rasio yang menunjukkan seberapa besar kontribusi aset dalam menciptakan laba bersih. Dengan kata lain, rasio ini digunakan untuk mengukur seberapa besar jumlah laba bersih yang akan dihasilkan dari setiap rupiah dana yang tertanam dalam total aset. 
Semakin tinggi hasil pengembalian atas aset berarti semakin tinggi pula jumlah laba bersih yang dihasilkan setiap rupiah dana yang tertanam dalam total aset. Sebaliknya, semakin rendah hasil pengembalian atas aset berarti semakin rendah pula jumlah laba bersih yang dihasilkan dari setiap dana rupiah yang tertanam dalam total aset.

Leverage merupakan alat untuk mengukur seberapa besar perusahaan bergantung pada kreditur dalam membiayai aset perusahaan. Perusahaan dengan tingkat leverage tinggi adalah perusahaan yang sangat bergantung pada pinjaman luar untuk membiayai asetnya sehingga perusahaan akan sebisa mungkin melaporkan laba yang tinggi dan mengurangi biaya-biaya termasuk biaya untuk melakukan pengungkapan tanggung jawab sosial. Sedangkan perusahaan dengan tingkat leverage yang rendah adalah perusahaan yang lebih banyak membiayai sendiri aset perusahannya sehingga perusahaan memiliki biaya yang cukup untuk melakukan pengungkapan tanggung jawab sosial.

Leverage dapat diukur dengan menggunakan Debt to Equity Ratio (DER). Hery (2016, hal.168) menyatakan bahwa Debt to Equity Ratio (DER) merupakan rasio yang digunakan untuk mengukur besarnya proporsi utang terhadap modal. Rasio ini dihitung sebagai hasil bagi antara total utang dengan modal. Rasio ini berguna untuk mengetahui besarnya perbandingan antara jumlah dana yang disediakan oleh kreditur dengan jumlah yang berasal dari pemilik perusahaan. Dengan kata lain, rasio berfungsi untuk mengetahui berapa bagian dari setiap rupiah modal yang dijadikan sebagai jaminan utang. Rasio ini memberikan petunjuk umum tentang kelayakan kredit dan risiko keuangan debitur.

Penelitian Isna Hardiani (2016) menunjukkan bahwa Profitabilitas yang diukur dengan Return On Assets dan Size perusahaan tidak memiliki pengaruh terhadap pengungkapan tanggung jawab sosial perusahaan. Sedangkan menurut Eka Syailendra Saputra (2016) menunjukkan bahwa Profitabilitas yang diukur dengan Return On Assets tidak berpengaruh positif terhadap jumlah pengungkapan CSR, dan Size yang diukur dengan total assets berpengaruh negatif terhadap jumlah pengungkapan CSR.

\section{Rumusan Masalah}

Berdasarkan latar belakang di atas, maka dalam penelitian ini permasalahan dirumuskan sebagai berikut :

1. Apakah Size berpengaruh terhadap pengungkapan tanggung jawab sosial?

2. Apakah ROA berpengaruh terhadap pengungkapan tanggung jawab sosial?

3. Apakah DER berpengaruh terhadap pengungkapan tanggung jawab sosial?

4. Apakah Size, ROA, DER berpengaruh terhadap pengungkapan tanggung jawab sosial?

\section{Tujuan Penelitian}

1. Untuk mengetahui pengaruh Size terhadap pengungkapan tanggung jawab sosial.

2. Untuk mengetahui pengaruh ROA terhadap pengungkapan tanggung jawab sosial.

3. Untuk mengetahui pengaruh DER terhadap pengungkapan tanggung jawab sosial.

4. Untuk mengetahui pengaruh Size, ROA, DER terhadap pengungkapan tanggung jawab sosial. 


\section{LANDASAN TEORI}

\section{Tanggung Jawab Sosial Perusahaan}

Kondisi iklim yang tidak menentu saat ini yang ditandai dengan menipisnya ozon dan global warming telah menggerakkan pemerintah negara-negara maju dan berkembang untuk ambil bagian dalam menciptakan regulasi yang ramah lingkungan. Pemerintah Indonesia sadar betul akan hal tersebut, sehingga merasa perlu adanya aturan terkait dengan tanggung jawab social dalam lingkungan. Undang-Undang No.40 tahun 2007 pasal 74 ayat 1 menyebutkan bahwa Perseroan yang menjalankan bisnisnya di bidang sumber daya alam dan di bidang yang berkaitan dengan sumber daya alam wajib melaksanakan tanggung jawab sosial dan lingkungan. Sangat mudah mengindikasi Perseroan yang menjalankan usahanya di bidang sumber daya alam. Perseroan ini adalah perusahaan yang mengeksploitasi sumber daya alam seperti pertambangan, perkebunan, dan pemegang hak penebangan hutang dan lain-lain.

Perusahaan yang menjalankan usahanya di bidang sumber daya alam dan di bidang yang berkaitan dengan sumber daya alam wajib menyusun laporan pelaksanaan tanggung jawab sosial dan lingkungan sebagai bagian dari laporan tahunan yang akan dipertanggungjawabkan oleh Direksi di depan RUPS tahunan. Laporan ini sebaiknya berisi program-program sosial dan lingkungan Perseroan yang telah dilaksanakan selama tahun buku yang berakhir.

Berdasarkan Undang-Undang No.40 tahun 2007 pasal 74 ayat 2 menyebutkan bahwa tanggung jawab social dan lingkungan Perseroan wajib dianggarkan dan diperhitungkan sebagai biaya Perseroan yang besarnya ditentukan dengan memperhatikan kepatutan dan kewajaran. Perseroan wajib menyisihkan dana untuk keperluan pelaksanaan program social dan lingkungan yang telah dicanangkannya. Sebaiknya Perseroan membentuk suatu unit kerja atau satuan tugas yang ditunjuk dari karyawan Perseroan atau dari luar Perseroan yang bertanggung jawab mengelola dana tersebut dan bertanggung jawab langsung kepada direksi.

Bagaimana pencatatan biaya sosial dan lingkungan dilakukan? DSAK-IAI pernah mengeluarkan ISAK 3, Interpretasi tentang perlakuan akuntansi atas pemberian sumbangan dan bantuan (PSAK 21 tentang akuntansi ekuitas) paragraph 33 yang menyebutkan bahwa saldo laba tidak boleh dibebankan atau dikreditkan dengan pospos yang seharusnya diperhitungkan pada laporan laba rugi tahun berjalan. Ada dua perlakuan atas biaya tanggung jawab sosial menurut ISAK 3 tersebut, yaitu: (1) sebagai beban usaha, dan (2) dikapitalisasi. Apabila biaya tanggung jawab sosial tidak bisa dikaitkan langsung dengan perolehan suatu aktiva, maka biaya tersebut harus dibebankan pada saat terjadinya dengan menggunakan dasar akrual. Biaya sosial dan lingkungan tidak dibebankan pada saat dibayarkan, melainkan pada saat terdapat kewajiban konstruktif atau legal pada Perseroan (Keputusan RUPS atau Direksi).

Ada kalanya suatu biaya sosial dan lingkungan terkait erat dengan perolehan aset tetap baik berwujud maupun tidak berwujud, misalnya sebagai kompensasi pendirian pabrik, Perseroan wajib mendirikan sekolah dan fasilitas umum masyarakat setempat. Perseroan wajib melakukan kapitalisasi atas biaya kompensasi yang telah 
dikeluarkan dan mencatatnya sebagai bagian harga perolehan aset tetap.

Menurut Wardani (2013), Tanggung jawab sosial perusahaan (Corporate Social Responsibility) adalah suatu konsep bahwa suatu organisasi khususnya (namun bukan hanya) perusahaan adalah memiliki suatu tanggung jawab terhadap konsumen, karyawan, pemegang saham, komunitas, dan lingkungan dalam aspek operasional perusahaan. CSR berhubungan erat dengan dengan "pembangunan berkelanjutan", dimana ada argumentasi bahwa suatu perusahaan dalam melaksanakan aktivitasnya harus mendasarkan keputusannya tidak semata berdasarkan faktor keuangan, misalnya keuntungan atau dividen melainkan juga harus berdasarkan konsekuensi sosial dan lingkungan untuk saat ini maupun untuk jangka panjang.

\section{Return On Assets (ROA)}

Tujuam akhir yang ingin dicapai suatu perusahaan adalah memperoleh laba yang maksimal. Manajemen perusahaan dituntut harus mampu untuk memenuhi target yang telah ditetapkan. Rasio profitabilitas merupakan rasio untuk menilai kemampuan perusahaan dalam mencari laba. Hasil pengukuran tersebut dapat dijadikan alat evaluasi kinerja manajemen selama ini.

Tujuan penggunaan rasio profitabilitas adalah: (1) untuk mengukur laba yang diperoleh perusahaan dalam satu periode tertentu. (2) menilai posisi laba perusahaan tahun sebelumnya dengan tahun sekarang. (3) menilai perkembangan laba dari waktu ke waktu. (4) menilai besarnya laba bersih sesudah pajak dengan modal sendiri. (5) mengukur produktivitas dari seluruh dana perusahaan yang digunakan baik modal pinjaman maupun modal sendiri.

ROA merupakan rasio yang menunjukkan hasil atas jumlah aset yang digunakan dalam perusahaan. ROA juga merupakan suatu ukuran tentang efektivitas manajemen dalam mengelola investasinya. Semakin kecil rasio ini semakin kurang baik, dan sebaliknya.

\section{Debt to Equity Ratio (DER)}

DER merupakan rasio yang digunakan untuk menilai utang dengan ekuitas. Rasio ini dihitung dengan cara membandingkan antara seluruh utang terhadap seluruh ekuitas. Rasio ini berguna untuk mengetahui jumlah dana yang disediakan kreditor dengan pemilik perusahaan. Rasio ini berfungsi untuk mengetahui setiap rupiah modal sendiri yang dijadikan untuk jaminan utang. rasio ini digunakan untuk mengukur seberapa besar jumlah laba bersih yang akan dihasilkan dari setiap rupiah dana yang tertanam dalam total aset.

Bagi kreditur, semakin rasio ini maka akan semakin tidak menguntungkan karena akan semakin besar risiko yang ditanggung atas kegagalan yang mungkin terjadi di perusahaan. Namun, bagi perusahaan semakin besar rasio ini akan semakin baik. Sebaliknya, dengan rasio yang rendah, semakin tinggi tingkat pendanaan yang disediakan pemilik dan semakin besar batas pengamanan bagi peminjam jika terjadi kerugian atau penyusutan terhadap nilai aktiva. Perusahaan dengan arus kas yang stabil biasanya memiliki rasio yang lebih tinggi dari rasio kas yang kurang stabil. 


\section{Size Perusahaan}

Ukuran perusahaan merupakan skala yang digunakan dalam menentukan besar kecilnya suatu perusahaan. ukuran perusahaan menggambarkan besar kecilnya suatu perusahaan yang ditunjukkan oleh total aset, jumlah penjualan, rata-rata total aset.

Pengaruh variabel ukuran perusahaan terhadap CSR menurut teori stakeholder yaitu semakin besar suatu perusahaan maka akan semakin banyak pihak-pihak yang menjadi bagian dari stakeholder perusahaan, sehingga semakin luas jangkauan pertanggung jawaban sosial perusahaan. Menurut Sembiring (2005), bahwa semakin besar perusahaan maka biaya keagenannya yang muncul juga semakin besar, untuk mengurangi biaya keagenan tersebut perusahaan cenderung mengungkapkan informasi yang lebih luas.

\section{Metodologi Penelitian}

\section{Waktu dan Tempat Penelitian}

Penelitian ini dilakukan selama 4 bulan yaitu dimulai bulan Maret sampai dengan Juni 2020. Penelitian ini dilakukan pada Bursa Efek Indonesia (BEI) yang beralamat di Menara I Jl. Sudirman Kav 52 -53 Jakarta Selatan 12190 Indonesia, dengan melalui website BEI yaitu www.idx.co.id

\section{Desain Penelitian}

Desain penelitian yang digunakan adalah penelitian kausal (causal research) yang merupakan penelitian untuk mengetahui pengaruh antara satu atau lebih variabel bebas terhadap variabel terikat.

\section{Variabel Penelitian}

Variabel yang digunakan dalam penelitian ini adalah sebagai berikut:

a. Variabel bebas atau independen yaitu size perusahaan (X1), ROA (X2), dan DER (X3). Size perusahaan diproksikan dengan Ln total aset. ROA merupakan rasio yang menunjukkan seberapa besar kontribusi aset dalam menciptakan laba bersih. ROA dihitung dengan cara membagi laba bersih setelah dengan total aset. DER merupakan rasio yang digunakan untuk mengukur besarnya proporsi utang terhadap modal. DER dihitung dengan cara membagi total kewajiban dengan ekuitas.

b. Variabel terikat atau dependen yaitu pengungkapan tanggung jawab sosial (CSR) yang diukur dengan menggunakan Index Luas Pengungkapan CSR (CSRI). Variabel ini diukur dengan menggunakan pendekatan dikotomi yaitu setiap item CSR dalam instrument penelitian diberi nilai 1 jika diungkapkan, dan nilai 0 jika tidak diungkapkan. Selanjutnya, skor dari setiap item dijumlahkan untuk memperoleh keseluruhan skor untuk setiap perusahaan. 


\section{Jenis dan Sumber Data}

Penelitian ini menggunakan data sekunder, yaitu data yang diperoleh dari pihak lain atau data yang telah tersedia. Data sekunder dikumpulkan, dicatat dan diolah sendiri data yang sudah tersedia. Data tersebut diperoleh dari website Bursa Efek Indonesia (www.idx.co.id).

\section{Populasi dan Sampel}

Dalam penelitian ini populasi yang digunakan yaitu perusahaan property and real estate yang terdaftar di Bursa Efek Indonesia periode 2015 - 2017, dan sampel dalam penelitian ini menggunakan metode Purposive Sampling. Adapun kriteria yang digunakan dalam penelitian ini adalah sebagai berikut : (1) Perusahaan property and real estate yang terdaftar di BEI pada periode tahun 2015 sampai dengan tahun 2017. (2) Perusahaan yang menyajikan data keuangan yang lengkap selama periode tahun 2015 sampai dengan tahun 2017. (3) Perusahaan yang menyajikan laporan keuangan tahunan yang dinyatakan rupiah. (4) Perusahaan yang memperoleh laba selama periode penelitian yaitu tahun 2015 sampai dengan tahun 2017. Dan (5) Perusahaan yang mengungkapkan CSR Disclosure dalam laporan tahunan..

\section{Metode Analisis Data}

\section{Statistik Deskriptif}

Statistik deskriptif yaitu suatu teknik analisis data yang berusaha menjelaskan atau menggambarkan berbagai karakteristik data. Program yang digunakan untuk mengolah data adalah Statistical Product and Service Solution versi 22.00.

\section{Uji Asumsi Klasik}

\section{a. Uji Normalitas}

Model regresi yang baik adalah memiliki distribusi data normal atau mendekati normal. Normalitas dapat dideteksi dengan menggunakan uji statistik, yaitu Kolmogorov-Smirnov Test (Imam Ghozali, 2016). Adapun kriteria pengujian adalah: (1) apabila nilai signifikan Kolmogorov-Smirnov Test adalah $<0.05$ maka data residual tidak berdistribusi normal, dan sebaliknya (2) apabila nilai signifikan KolmogorovSmirnov Test adalah $>0.05$ maka data residual berdistribusi normal.

\section{b. Uji Autokorelasi}

Model regresi yang baik seharusnya tidak menunjukkan autokorelasi. Untuk mendeteksi ada tidaknya autokorelasi, maka nilai DW (Durbin Watson) akan dibandingkan dengan tabel DW. Kriteria yang dipakai adalah sebagai berikut: (1) Jika d lebih kecil dari dL atau lebih besar dari (4-dL) maka hipotesis nol ditolak, yang berarti terdapat autokorelasi. (2) Jika d terletak antara dU dan (4-dU), maka hipotesis nol diterima, yang berarti tidak ada autokorelasi. (3) Jika d terletak antara dL dan dU atau dimana (4-dU) dan (4-dL), maka tidak menghasilkan kesimpulan yang pasti.

\section{c. Uji Multikolinieritas}

Jurnal Ilmiah Akuntansi dan Ekonomi Volume. 1 Nomor. 5 Februari 2020

Hal. 89 
Model regresi yang baik seharusnya tidak terjadi korelasi diantara variabel independen (Imam Ghozali, 2016). Untuk mendeteksi ada tidaknya multikolinearitas dalam suatu persamaan regresi adalah sebagai berikut: nilai Tolerance yang rendah maka akan berakibat pada VIF yang tinggi, dan ini berarti terjadi multikolinearitas. Dan sebaliknya, persamaan regresi tidak terjadi multikolinieritas jika nilai Tolerance $>$ 0.10 , dan besarnya VIF $<10$.

\section{d. Uji Heteroskedastisitas}

Model regresi yang baik adalah tidak terjadi heteroskedastisitas. Menurut Imam Ghozali (2016) uji Heteroskedastisitas bertujuan untuk mengetahui apakah sebuah model dalam regresi terjadi ketidaksamaan varians residual dari satu pengamatan ke pengamatan yang lain tetap, maka hal tersebut disebut homokedastisitas. Jika varians berbeda, disebut dengan heteroskedastisitas. Ada beberapa cara yang dapat dilakukan untuk melakukan uji heteroskedastisitas, diantaranya dengan uji glejser. pengujian heteroskedastisitas dalam penelitian ini menggunakan uji glejser.

\section{Analisis Regresi Linier Berganda}

Analisis regresi linier berganda berguna untuk menganalisa hubungan linier antara 2 variabel independen atau lebih dengan 1 variabel dependen. Dalam uji regresi peneliti menggunakan regresi linier berganda untuk mencari pengaruh antar variabel dengan model sebagai berikut:

$$
\mathbf{Y}=\mathbf{a}+\boldsymbol{\beta} 1 \mathbf{X 1}+\boldsymbol{\beta 2} \mathbf{X} 2+\beta 3 \times 3+\mathbf{e}
$$

Keterangan :

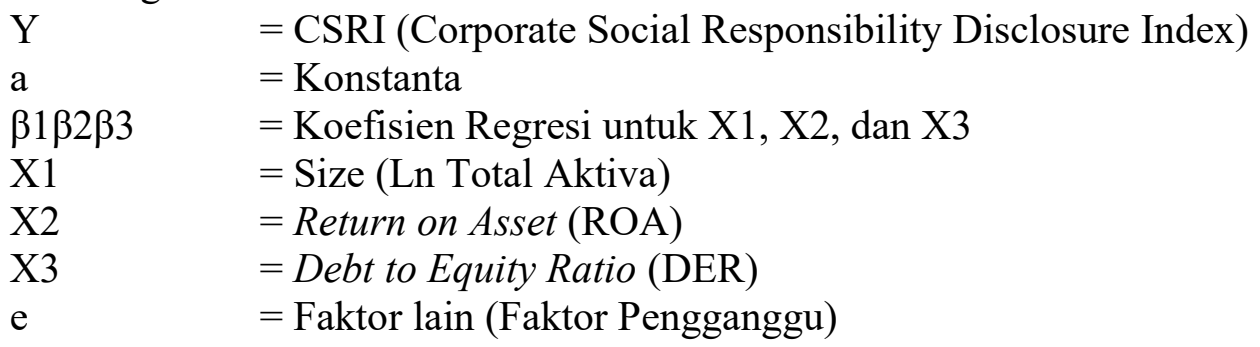

\section{Uji Hipotesis}

\section{a. Koefisien Determinasi $\left(\mathbf{U} \mathbf{j i} \mathbf{R}^{2}\right)$}

Untuk menyatakan besar kecilnya sumbangan variabel $\mathrm{X}$ terhadap $\mathrm{Y}$ dapat ditentukan dengan koefisien determinasi. Pada koefisien determinasi $\left(\mathrm{R}^{2}\right)$ pada intinya mengukur seberapa jauh kemampuan model dalam menerangkan variasi variabel dependen. Nilai $\mathrm{r}^{2}$ adalah antara 0 dan $1\left(0<\mathrm{R}^{2}<1\right)$, dimana suatu regresi yang baik akan menghasilkan nilai $\mathrm{r}^{2}$ yang tinggi. Hal ini berarti bahwa keseluruhan variabel bebas secara bersama-sama mampu menerangkan variabel terikatnya. Sedangkan $\mathrm{r}^{2}$ yang kecil berarti kemampuan variabel-variabel dependen sangat terbatas (Ghozali, 2016).

\section{b. Uji statistik t (Uji Signifikan Parsial)}

Uji hipotesis dalam penelitian ini diuji menggunakan model regresi linier berganda. Uji statistik t pada dasarnya menunjukkan seberapa jauh pengaruh satu variabel independen secara individual dalam menerangkan variasi varibel dependen. 
Hipotesis nol (H0) yang hendak diuji adalah apakah suatu parameter sama dengan nol, atau $\mathrm{H0}:$ bi $=0$. Hipotesis alternatifnya $(\mathrm{HA})$ parameter suatu variabel tidak sama dengan nol, atau HA : ba $\neq 0$. Uji parsial ditunjukkan oleh tabel Coeficients dalam hasil output SPSS. Selanjutnya untuk mengetahui signifikan pengaruh atau hubungan antar variabel dapat dilakukan pengambilan keputusan dengan kriteria sebagai berikut: (1) jika probabilitas $>0.05$, maka H0 tidak dapat ditolak, jadi variance sama. (2) jika probabilitas $<0.05$, maka $\mathrm{H} 0$ ditolak, jadi variance berbeda.

\section{c. Uji statistik F (Uji Signifikan Simultan)}

Uji simultan ditunjukkan oleh tabel Anova. Uji statistik F menunjukkan apakah semua variabel independen yang dimasukkan dalam model mempunyai pengaruh secara bersama-sama terhadap variabel terikat. Hipotesis nol $(\mathrm{H} 0)$ yang hendak diuji adalah apakah semua parameter dalam model sama dengan nol, atau $\mathrm{H} 0: \mathrm{b} 1=\mathrm{b} 2=\ldots$ $=\mathrm{bk}=0$. Hipotesis alternatifnya adalah tidak semua parameter secara simultan sama dengan nol, atau HA : $\mathrm{b} 1 \neq \mathrm{b} 2 \neq \ldots \ldots \neq \mathrm{bk} \neq 0$. Menentukan tingkat signifikan $(\alpha)$ yaitu sebesar 5\% dapat dilakukan dengan berdasarkan nilai probabilitas, dengan cara: (1) Jika probabilitas $>0.05$ maka H0 tidak dapat ditolak, jadi variance sama. (2) Jika probabiliitas $<0.05$ maka H0 ditolak, variabel independen secara simultan mempengaruhi variabel terikat.

\section{Analisis Hasil dan Pembahasan}

\section{Statistik Deskriptif}

Pengolahan data ini menggunakan program Statistical Package for the Social Science (SPSS). Berdasarkan kriteria yang telah ditepkan dengan menggunakan metode purposive sampling maka perusahaan property and real estate yang terdaftar di Bursa Efek Indonesia yang memenuhi persyaratan sebanyak 20 perusahaan. Periode penelitian yang digunakan adalah 3 tahun yaitu tahun 2015-2017 sehingga sampel penelitian ini berjumlah 60 sampel.

a. Size. Size diproksikan Ln Total Aset. besarnya Size mempunyai nilai minimum sebesar 22,010, nilai maksimum sebesar 31,460, nilai rata-rata (mean) sebesar 27,1298, dan standar deviasi sebesar 3,1172. Total Aset paling rendah yaitu PT. PT. Metropolitan Land Tbk pada tahun 2016, nilai maksimum sebesar 31,460 diperoleh dari total aset paling besar tahun 2017 yaitu PT. PT. Bumi Serpong Damai Tbk.

b. Return on Asset (ROA). Besarnya ROA mempunyai nilai minimum sebesar 0,005, nilai maksimum sebesar 0,403, nilai rata-rata (mean) sebesar 0,05995, dan standar deviasi sebesar 0,061951. ROA dengan nilai minimium 0,005 yang diperoleh dari PT. Duta Anggada Realty Tbk., dan nilai maksimum 0,403 diperoleh dari PT. Ciputra Development.

c. Debt to Equity Ratio (DER). Hasil Uji Statistik Deskriptif, menunjukkan bahwa besarnya DER mempunyai nilai minimum sebesar 0,252, nilai maksimum sebesar 1,992, nilai rata-rata (mean) sebesar 0,99158, dan standar deviasi sebesar 0,420851. DER dengan nilai minimium 0,252 yang diperoleh dari PT. Suryamas 
Dutamakmur Tbk dan nilai maksimum 1,992 diperoleh dari PT. Bekasi Fajar Industrial Estate Tbk.

d. CSRI (Corporate Social Responsibility Disclosure Index). Berdasarkan pengujian yang dilakukan, besarnya CSR mempunyai nilai minimum sebesar 0,218 , nilai maksimum sebesar 0,577, nilai rata-rata (mean) sebesar 0,43353, dan standar deviasi sebesar 0,090446. CSR dengan nilai minimum 0,218 yang diperoleh dari total CSR PT. Suryamas Dutamakmur Tbk dan nilai maksimum 0,577 dari total CSR yang terdapat pada 4 perusahaan property and real estate yaitu PT. Ciputra Development Tbk tahun 2015, PT. Bumi Serpong Damai Tbk tahun 2016 dan tahun 2017, PT. Goa Makassar Tourism Development Tbk. tahun 2016, serta PT. Metropolitan Land Tbk tahun 2016.

\section{Uji Asumsi Klasik}

Hipotesis dalam penelitian ini diuji dengan menggunakan teknik analisis regresi linier berganda. Dalam analisis regresi linier berganda harus memenuhi beberapa pengujian asumsi klasik. Uji asumsi klasik yang dilakukan dalam penelitian ini meliputi uji normalitas, uji kolmogorov-smirnov, uji multikolinieritas, uji autokolerasi, dan uji heteroskedastisitas. Berikut ini adalah uji asumsi klasik.

\section{Uji Normalitas}

Normalitas dapat diketahui dengan melihat tabel One-Sample KolmogorovSmirnov Test pada kolom Asymp.Sig (2-tailed) yaitu jika p value (sig) $>0.05$ maka dapat disimpulkan bahwa data yang diambil dari populasi berdistribusi normal. Berdasarkan hasil output SPSS, diperoleh hasil Asymp.Sig. (2-tailed) untuk variabel Size (X1), ROA (X2), DER (X3), dan CSR (Y) adalah sebesar 0,200 > 0.05. Karena Asymp. Sig $>$ dari 0.05, maka dapat disimpulkan bahwa data yang diambil dari populasi berdistribusi normal.

\section{Uji Multikolinearitas}

Untuk mendeteksi ada atau tidaknya multikolinearitas dalam suatu persamaan regresi adalah dengan melihat nilai Tolerance dan VIF pada tabel coefficients. Berdasarkan pengolahan data yang dilakukan, diperoleh hasil sebagai berikut: (a) variabel Size (X1) diperoleh nilai Tolerance 1,640 > 0,10 dan nilai VIF 1,108<10. (b) variabel ROA (X2) diperoleh nilai Tolerance 0,567 $>0,10$ dan nilai VIF $1,007<10$. (c) Variabel DER (X3) diperoleh nilai Tolerance 2,700 > 0,10 dan nilai VIF 1,103< 10. Berdasarkan data di atas dapat disimpulkan bahwa antar variabel independen tidak terjadi multikolinearitas.

\section{Uji Autokorelasi}

Model regresi yang baik seharusnya adalah regresi yang bebas dari autokorelasi. Metode pengujian yang sering digunakan untuk mengetahui autokorelasi adalah dengan uji Durbin-Watson (Uji DW). nilai Durbin-Watson (dw) 1,800, pada tabel Durbin-Watson dengan diperoleh nilai $\mathrm{du}=1,6889$; dan nilai $\mathrm{dl}=1,4797$. Dengan kriteria du $<$ dw $<4$-du , maka 1,6889 $<1,800<2,3111$ atau lebih besar dari du $(1,800$ 
$>1,6889)$ dan kurang dari 4-du ( 4- 1,6889 = 2,3111) maka dapat di simpulkan tidak terdapat autokorelasi.

\section{Uji Heteroskedastisitas}

Uji Heterokedastisitas bertujuan untuk menguji apakah dalam model regresi terjadi ketidaksamaan variance dari residual satu pengamatan ke pengamatan yang lain. Jika variance dari residual satu pengamatan ke pengamatan yang lain tetap, maka disebut homokedastisitas dan jika berbeda disebut heterokedastisitas. Untuk mengetahui ada atau tidaknya heteroskedastisitas, penelitian ini menggunakan uji glejser. Uji glejser yaitu meregresi nilai absolut residual terhadap variabel independensi. Jika nilai probabilitas signifikasinya diatas tingkat kepercayaan 5\% maka dapat di simpulkan model regresi tidak mengandung adanya heteroskedastisitas (Ghozali, 2016). Berdasarkan hasil pengujian yang dilakukan, semua variabel memperoleh nilai lebih dari 0,05. Maka, dapat disimpulkan bahwa tidak terdapat heteroskedastisitas.

\section{Analisis Regresi Linier Berganda}

Berikut ini adalah tabel hasil analisis regresi linier berganda dengan bantuan SPSS. Berdasarkan tabel di bawah ini, maka dapat dibuat persamaan regresi linier berganda sebagai berikut :

$$
\mathrm{Y}=0,183+0,006 \mathrm{SIZE}+0,104 \mathrm{ROA}+0,076 \mathrm{DER}+\varepsilon
$$

Tabel analisis regresi linier berganda

\begin{tabular}{|l|r|r|r|r|r|}
\hline \multirow{2}{*}{ Model } & \multicolumn{2}{|c|}{$\begin{array}{c}\text { Unstandardized } \\
\text { Coefficients }\end{array}$} & $\begin{array}{c}\text { Standardized } \\
\text { Coefficients }\end{array}$ & & \\
\cline { 2 - 4 } & \multicolumn{1}{c|}{$\mathrm{B}$} & Std. Error & \multicolumn{1}{|c|}{ Beta } & \multicolumn{1}{c|}{$\mathrm{t}$} & Sig. \\
\hline 1 (Constant) &, 183 &, 115 & & 1,585 &, 119 \\
Size &, 006 &, 004 &, 215 & 1,640 &, 107 \\
\hline ROA &, 104 &, 183 &, 071 &, 567 &, 573 \\
\hline DER &, 076 &, 028 &, 353 & 2,700 &, 009 \\
\hline
\end{tabular}

a. Dependent Variable: CSR

Sumber : Data dari Output SPSS

Dari persamaan tersebut bisa diambil kesimpulan sebagai berikut:

1. Konstanta berdasarkan hasil regresi sebesar 0,183. Nilai ini artinya Ukuran Perusahaan (SIZE), Return On Assets (ROA), dan Debt To Equity Ratio (DER) nilainya 0, maka nilai Pengungkapan Tanggung Jawab Sosial Perusahaan (CSR) sebesar 0,183 .

2. Koefisien regresi ukuran perusahaan (SIZE), hasil ini menunjukkan koefisien positif sebesar 0,006. Artinya jika ukuran perusahaan mengalami kenaikan satu satuan, maka keputusan untuk melakukan pengungkapan tanggung jawab sosial perusahaan akan mengalami peningkatan sebesar 0,006.

3. Koefisien regresi Return On Assets (ROA) $=0,104$ hasil ini menunjukkan koefisien positif sebesar 0,104. Artinya jika ROA mengalami kenaikan satu satuan, 
maka keputusan untuk melakukan pengungkapan tanggung jawab sosial perusahaan akan mengalami peningkatan sebesar 0,104.

4. Koefisien regresi Debt To Equity Ratio (DER) $=0,076$ hasil ini menunjukkan koefisien positif sebesar 0,076. Artinya jika DER mengalami kenaikan satu satuan, maka keputusan untuk melakukan pengungkapan tanggung jawab sosial perusahaan akan mengalami peningkatan sebesar 0,076.

\section{Uji Hipotesis}

\section{Koefisien determinasi}

Koefisien determinasi $\left(\mathrm{R}^{2}\right)$ digunakan untuk mengukur seberapa jauh kemampuan model dapat menjelaskan variasi variabel dependen. Nilai $\mathrm{R}^{2}$ yang kecil berarti kecil juga kemampuan variabel-variabel independen dalam menjelaskan variasi variabel dependen yang sangat terbatas. Koefisien determinasi adalah kuadrat dari nilai korelasi pada tabel Model Summary Output SPSS yang dapat dihasilkan sebagai berikut:

\begin{tabular}{|l|c|r|r|r|}
\hline Model & $\mathrm{R}$ & R Square & $\begin{array}{c}\text { Adjusted R } \\
\text { Square }\end{array}$ & $\begin{array}{c}\text { Std. Error of } \\
\text { the Estimate }\end{array}$ \\
\hline 1 &, $361^{\mathrm{a}}$ &, 130 &, 084 &, 086586 \\
\hline
\end{tabular}

a. Predictors: (Constant), SIZE, ROA, DER

b. Dependent Variable: CSR

Berdasarkan tabel di atas diperoleh bahwa nilai koefisien determinasi (R Square) sebesar 0.130 atau sebesar $13 \%$. Hal ini berarti bahwa variabel Size, ROA dan DER mampu menjelaskan variabel CSR sebesar 13\%, sedangkan sisanya $87 \%$ dipengaruhi oleh faktor-faktor lain yang tidak dimasukkan dalam model dalam penelitian ini.

\section{Uji statistik $\mathbf{F}$ (uji signifikan simultan)}

Uji statistik F menunjukkan apakah semua variabel independen yang dimasukkan dalam model mempunyai pengaruh secara bersama-sama terhadap variabel terikat. Pengujian dilakukan dengan tingkat signifikansi 0.05 atau $\alpha=5 \%$. Uji F dilihat dalam tabel ANOVA output SPSS dalam kolom sig, jika probabilitas $<0.05$ maka dapat dikatakan terdapat pengaruh secara bersama-sama variabel independen terhadap variabel dependen dan model regresi bisa dipakai untuk memprediksi variabel dependen, dan sebaliknya. Berikut ini adalah kriteria pengujian yang dilakukan:

a. Jika Sig $<0.05$, maka Ho ditolak dan Ha diterima.

b. Jika Sig $>0.05$, maka Ho diterima dan Ha ditolak.

\begin{tabular}{|c|c|c|c|c|c|c|}
\hline \multicolumn{2}{|c|}{ Model } & Sum of Squares & Df & Mean Square & $\mathrm{F}$ & Sig. \\
\hline 1 & Regression & ,063 & 3 & 021 & 2,792 &, $049^{b}$ \\
\hline & Residual & ,420 & 56 & ,007 & & \\
\hline & Total & ,483 & 59 & & & \\
\hline
\end{tabular}

a. Dependent Variable: CSR

b. Predictors: (Constant), SIZE, ROA, DER

Hasil Uji Anova atau F-test pada menunjukan F-hitung sebesar 2,792 dengan tingkat signifikansi 0,049 sedangkan $\mathrm{F}_{\text {table }}(\mathrm{F}=\mathrm{k}: \mathrm{n}-\mathrm{k}) \mathrm{F}=3 ; 57=2,77$. Diketahui bawah $\mathrm{F}_{\text {hitung }}>\mathrm{F}_{\text {tabel }}(2,792>2,77)$ dan tingkat signifikansi $0,049<0,05$ maka Ha 
diterima dan $\mathrm{H}_{\mathrm{o}}$ ditolak yang artinya bahwa Size, ROA, dan DER secara simultan berpengaruh signifikan terhadap CSR.

\section{Uji statistik t (uji signifikan parsial)}

Uji $\mathrm{t}$ yaitu suatu uji untuk mengetahui signifikansi pengaruh variabel independen (Size, ROA, DER) secara parsial menerangkan terhadap variabel dependen (CSR). Pengujian ini dinilai dengan tingkat signifikansi 0.05 atau $\alpha=5 \%$. Berikut ini adalah kriteria pengujian yang dilakukan:

1. Jika Nilai Sig $<0.05$, maka Ho ditolak dan Ha diterima.

2. Jika Nilai Sig $>0.05$, maka Ho diterima dan Ha ditolak.

Berdasarkan tabel analisis regresi linier berganda di atas, maka dapat dijelaskan mengenai pengaruh secara parsial masing-masing variabel independen sebagai berikut:

\section{a. Pengaruh Size terhadap CSR}

Dari pengujian statistik menunjukan bahwa $t_{\text {hit }}<t_{\text {tabel }}$ yaitu 1,$640 ;<$ 2,00324 sedangkan nilai signifikan yang dihasilkan lebih besar dari alpha $(\alpha)$, yakni $0,107>0,05$. Hal ini berarti menunjukkan bahwa keputusan yang diambil adalah menolak Hipotesis alternatif. Sehingga dapat disimpulkan bahwa secara parsial Size tidak berpengaruh terhadap CSR.

Hasil penelitian ini menunjukkan bahwa parameter ukuran perusahaan (size) tidak hanya dilihat dari jumlah aset yang dimiliki, akan tetapi dapat juga dilihat dari rasio likuiditas atau laba yang dimiliki. Hal ini berarti pengungkapan CSR tidak bergantung pada besar kecilnya perusahaan dan dapat disimpulkan besar ataupun kecil ukuran sebuah perusahaan, perusahaan wajib mengungkapkan tanggung jawab sosial, karena setiap aktivitas perusahaan dapat menimbulkan dampak pada lingkungan sekitar perusahaan.

Hasil penelitian ini tidak mendukung penelitian Nurhayati (2016) yang mengatakan bahwa ukuran perusahaan berpengaruh terhadap pengungkapan tanggung jawab sosial (CSR). Akan tetapi, penelitian ini mendukung hasil penelitian yang dilakukan oleh Isna (2016) yang mengatakan bahwa ukuran perusahaan tidak berpengaruh tehadap pengungkapan tanggung jawab sosial perusahaan.

\section{b. Pengaruh ROA terhadap CSR}

Dari pengujian statistik menunjukan bahwa $t_{\text {hitun }} t_{\text {tabel }}$ yaitu $0,567<$ 2,00324 sedangkan nilai signifikan yang dihasilkan lebih besar dari alpha $(\alpha)$, yakni $0,573>0,05$. Hal ini berarti menunjukkan bahwa keputusan yang diambil adalah menolak Hipotesis alternative. Berarti secara parsial ROA tidak berpengaruh terhadap CSR.

Hasil penelitian ini menunjukkan bahwa semakin tinggi angka profitabilitas perusahaan tersebut berarti perusahaan tersebut telah berkinerja dengan baik dan telah mendapatkan kepercayaan dari masyarakat sehingga property yang dijual selalu laku terjual dipasaran. Semakin besar profitabilitas maka akan semakin banyak aktivitas CSR yang akan diungkapkan perusahaan. Hal ini dilakukan untuk membangun image positif pada masyarakat dan juga menarik investor untuk menanamkan modalnya. 
Hasil penelitian ini tidak mendukung penelitian Tasya (2016) yang mengatakan bahwa profitabilitas yang diukur dengan ROA berpengaruh terhadap pengungkapan tanggung jawab sosial (CSR). Akan tetapi, penelitian ini mendukung hasil penelitian yang dilakukan oleh Isna (2016) dan Saputra (2016) yang mengatakan bahwa profitabilitas yang diukur dengan ROA tidak berpengaruh tehadap pengungkapan tanggung jawab sosial perusahaan.

\section{c. Pengaruh DER terhadap CSR}

Dari pengujian statistik menunjukan bahwa $t_{\text {hitun }}>t_{\text {tabel }}$ yaitu 2,700 $>$ 2,00324 sedangkan nilai signifikan yang dihasilkan lebih kecil dari alpha $(\alpha)$, yakni $0,009<0,05$. Hal ini berarti menunjukkan bahwa keputusan yang diambil adalah menerima Hipotesis alternative. Berarti secara parsial DER berpengaruh positif terhadap CSR.

Hasil penelitian ini menunjukkan bahwa aset yang dimiliki oleh perusahaan sebagian besar dibiayai oleh hutang, sehingga perusahaan berkewajiban untuk mengungkapkan tanggung jawab sosial perusahaan lebih banyak. Hal ini dilakukan agar investor dapat memperoleh keyakinan atas terjaminnya hak mereka sebagai kreditor agar tidak terjadi pelanggaran dalam pembayaran hutang.

Hasil penelitian ini tidak mendukung penelitian Tasya (2016) yang mengatakan bahwa leverage yang diukur dengan DER tidak berpengaruh terhadap pengungkapan tanggung jawab sosial perusahaan. Akan tetapi, penelitian ini mendukung hasil penelitian yang dilakukan oleh Saputra (2016), dan Nurhayati (2016) yang mengatakan bahwa leverage yang diukur dengan DER berpengaruh positif tehadap pengungkapan tanggung jawab sosial perusahaan

\section{KESIMPULAN DAN SARAN}

\section{Kesimpulan}

Adapun kesimpulan dalam penelitian ini adalah sebagai berikut:

1. Ukuran Perusahaan (Size) tidak berpengaruh terhadap pengungkapan tanggung jawab sosial perusahaan.

2. Return On Assets (ROA) tidak berpengaruh terhadap pengungkapan tanggung jawab sosial perusahaan.

3. Debt To Equity Ratio (DER) berpengaruh positif dan signifikan terhadap pengungkapan tanggung jawab sosial perusahaan.

4. Secara simultan Size, ROA, dan DER berpengaruh signifikan terhadap pengungkapan tanggung jawab sosial perusahaan. 


\section{Saran}

Berdasarkan kesimpulan diatas, maka peneliti mengajukan beberapa saran yaitu sebagai berikut:

1. Bagi peneliti selanjutnya diharapkan untuk mempertimbangkan dalam penambahan variabel independen lain seperti ukuran dewan komisaris, kepemilikan manajemen, tipe industri, pertumbuhan perusahaan dan lain sebagai yang dapat mempengaruhi pengungkapan tanggung jawab sosial perusahaan sehingga dapat menunjukkan korelasi antar variabel dependen dan variabel independen yang lebih baik.

2. Untuk peneliti selanjutnya disarankan untuk menambahkan sampel yang akan di teliti, tidak hanya meliputi perusahaan property and real estate, akan tetapi dapat diperluas pada kelompok perusahaan lainnya seperti perusahaan pada sektor pertambangan yang terdaftar di Bursa Efek Indonesia.

3. Bagi perusahaan, disarankan agar perusahaan dapat lebih terbuka lagi dalam mengungkapkan tanggung jawab sosial perusahaan terhadap masyarakat, mengingat antara perusahaan dan masyarakat saling memiliki kepentingan. Selain itu manfaat yang diperoleh bagi perusahaan adalah untuk membangun citra perusahaan yang positif kepada masyarakat serta dapat menarik investor untuk menanamkan modalnya.

\section{DAFTAR PUSTAKA}

Ghozali. 2016. Aplikasi Analisis Multivariate Dengan Program IBM SPSS. Semarang: Badan Penerbit Universitas Diponegoro.

Hardiani, Isna. 2016. "Pengaruh size dan profitabilitas perusahaan terhadap pengungkapan tanggung jawab sosial perusahaan pada subsektor pulp dan kertas yang terdaftar di BEI Tahun 2013-2015”. Jurnal Akuntansi Fakultas Ekonomi Universitas Gunadarma. Jakarta.

Hery. (2016). Analisis Laporan Keuangan: Integrated And Comprehensive Edition. Jakarta: PT. Grasindo

Kasmir. 2015. Analisis Laporan Keuangan. Jakarta : PT Raja Grafindo Persada.

Nugraha, Novia bani. 2015. "pengaruh corporate social responsibility, ukuran perusahaan, profitabilitas, leverage, dam capital intensity terhadap agresivitas pajak”.Skripsi. Semarang: Universitas Diponegoro.

Purba P. Marisi, 2008. Aspek Akuntansi - Undang-Undang Perseroan Terbatas, Edisi Pertama. Yogyakarta: Graha Ilmu. 
Saputra, Syailendra Eka. 2016. "Pengaruh leverage, profitabilitas, dan size terhadap pengungkapan corporate social responsibility pada perusahaan di bursa efek indonesia. Journal of economic and Economic Education Vol.5 No.1 , Hal : 7589.

Sembiring, R.A. 2005."karakteristik perusahaan dan pengungkapan tanggung jawab sosial: Studi empiris pada perusahaan yang tercatat di Bursa Efek Indonesia“" Simposium Nasional Akuntansi VIII.

Tasya, Elvira. 2016. "Pengaruh pertumbuhan perusahaan, profitabilitas, dan leverage terhadap pengungkapan tanggung jawab sosial perusahaan". Artikel Penelitian Fakultas Ekonomi Universitas Negeri Padang

Wardani, Nurul Kusuma. 2013. " Pengaruh karakteristik perusahaan terhadap pengungkapan Corporate social responsibility“. Skripsi. Semarang: Universitas Diponegoro. 